Mariusz GRABA

Krzysztof PRAŻNOWSKI

Michat SMIEJA

Dariusz WERESZCZYŃSKI

\title{
Application of biogas to supply the high compression ratio engine
}

The study concerns the use of biogas as a fuel for supplying a modified self-ignition engine. As a result of the modifications made, the compression ratio was reduced and the engine was equipped with an ignition system and an electronically activated engine throttle. The changes have made it possible to burn biogas in a high compression ratio engine. The paper presents the results of research conducted on a low power cogeneration system with engine that drives an electrical machine cooperating with a 380/400 V network. The analysis includes, among other things, the possibility of producing electricity using biogas. The paper presents the influence of regulatory parameters such as the volume and composition of the supplied gas mixture and the degree of throttle opening on the obtained engine operation indicators and the driven electric machine. The tests were carried out in relation to the obtained ecological indicators depending on the concentration in the exhaust of such substances as: $\mathrm{HC}, \mathrm{CO}, \mathrm{NO}_{x}$.

Key words: biogas, high compression ratio engine, emission, low power cogeneration system

\section{Introduction}

Combustion engines could be powered with different fuels. One of important fuel groups consists of gaseous fuels. There are fuels as generator gas with very low calorific value [5] from hydrogen [6] and fermentation gas (biogas) up to methane $\mathrm{CH}_{4}$. The properties of selected gaseous fuels are listed in Table 1. It should be noted that methane, which is the main component of biogas and natural gas is characterized by a high octane number. That allows it to supply engines with a high compression ratio and combust without knocking. Biogas can be made from agricultural waste, which makes it possible to use the energy contained in it.

Table 1. Properties characteristic for choosen gasenous fuels [8, 13]

\begin{tabular}{|c|c|c|c|c|c|}
\hline $\begin{array}{l}\text { Gasenous } \\
\text { fuel }\end{array}$ & $\begin{array}{l}\text { Density, } \\
\mathrm{kg} \cdot \mathrm{Nm}^{-3}\end{array}$ & $\begin{array}{l}\text { Calorific } \\
\text { value, } \\
\mathrm{MJ} \cdot \mathrm{Nm}^{-3}\end{array}$ & $\begin{array}{c}\text { Calorific value } \\
\text { of stechiom. } \\
\text { mixture, } \\
\mathrm{MJ} \cdot \mathrm{m}^{-3}\end{array}$ & $\begin{array}{c}\lambda \text { index for } \\
\text { the lower } \\
\text { flammable } \\
\text { limit }\end{array}$ & MON \\
\hline Methane & 0.714 & 35.8 & 3.18 & 2.00 & 110 \\
\hline Propane & 1.963 & 91 & 3.42 & 2.06 & 95 \\
\hline Butane & 2.588 & 118 & 3.44 & 1.70 & 92 \\
\hline Natural gas & 0.695 & 34.7 & 3.4 & 2.10 & $100-110$ \\
\hline Coal gas & 0.468 & 13 & 3.35 & - & 95 \\
\hline $\begin{array}{l}\text { Generator } \\
\text { gas }\end{array}$ & 1.015 & 5.65 & 2.6 & 4.35 & 105 \\
\hline $\begin{array}{l}\text { Illumina- } \\
\text { tion gas }\end{array}$ & 0.614 & 17 & 3.25 & 2.50 & 90 \\
\hline $\begin{array}{l}\text { Biogas 54\% } \\
\mathrm{CH}_{4} \\
\end{array}$ & 1.276 & 19.3 & 2.71 & 2.16 & 110 \\
\hline $\begin{array}{l}\text { Propane - } \\
\text { butane } \\
(50 \% / 50 \%)\end{array}$ & 2.080 & 96.5 & 3.35 & 1.91 & 95 \\
\hline Hydrogen & 0.089 & 10.8 & 3.03 & 10 & 130 \\
\hline
\end{tabular}

There are many opportunities to use energy from biogas. Very often, in the case of stationary applications, the conversion of energy contained in the biogas fuel is used for generating electricity. However, in order to improve the efficiency of the entire system, ie. to avoid energy losses,
CHP cogeneration systems are built to simultaneously generate electricity and heat. Further improvement of energy indicators is possible with the use of trigeneration systems in which, in addition to electricity and heat production, biogas energy can be used during the sorption process (adsorption and absorption of cold). Among the various methods of using biogas energy, one can distinguish the use of gas combustion in a piston combustion engine. For this purpose, compression-ignition or spark-ignition engines are used. In the case of an engine fueled with diesel fuel, some modifications are required. It can be use dual fuel supply system (diesel and biogas) or only biogas. In the second case, it is often necessary to change the some construction properties of the engine in order to lower the compression ratio and adding equipment with an ignition system similar to those used in engines operating in the Otto cycle $[4,14]$. In many cases, particularly relatively simple construction engines, the introduction of modifications does not lead to higher technical and economic expenses [14].

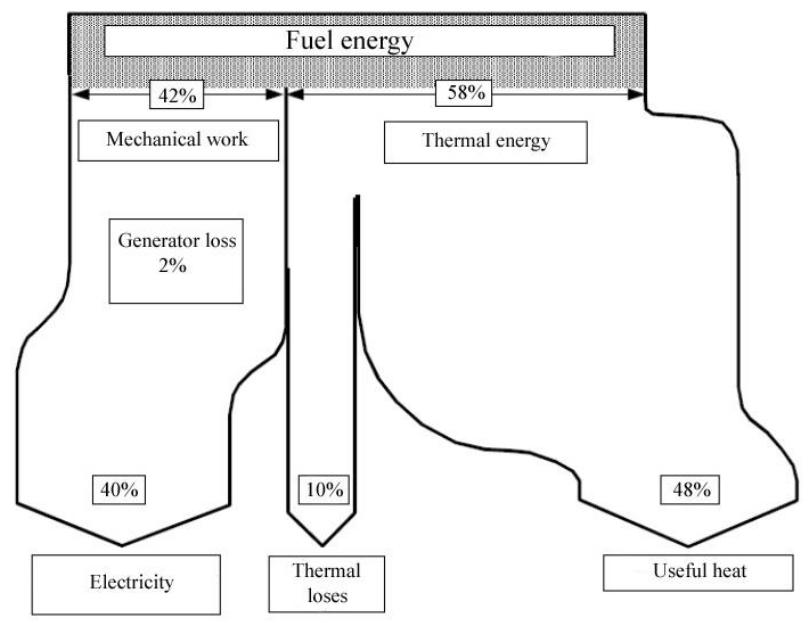

Fig. 1. Energy balance of an internal combustion engine operating in a cogeneration system [7] 
Therefore, it is possible to adapt existing engine constructions for biogas power supply with relatively small modifications. In addition, the use of an internal combustion engine in a cogeneration system allows to achieve a high overall efficiency of up to $90 \%$ [7, 19]. Efficiency with the inclusion only electrical energy generation very rarely exceeds $40 \%$ - Fig. 1 .

Other methods based on the use of, for example, Rankine, Stirling engine, micro-turbines or fuel cells are characterized by lower overall efficiency while working in a CHP.

\section{Biogas and combustion engine operating indexes}

The combustion of fuel in the engine is associated with the emission of harmful substances. Particularly in the diesel engine, it is important to reduce the emission of solid particles PM, but also the remaining other harmful exhaust components. In addition to the use of a environmental friendly design, the use of an appropriate fuel dosing system, and the aftertreatment method's, the type of fuel used and its detailed composition are important. Reduction of emissions is possible, for example, thanks to the use of catalytic fuel additives, which makes it possible to reduce PM emissions by up to over 60 percent [1]. However, the best results can be achieved using gas fuels, including those whose main component is methane.

Thanks to biogas supply, PM particulate emissions can be significantly reduce by up to $99 \%$, carbon dioxide by $25 \%$, and nitrogen oxides by up to $95 \%$. At the same time, it is possible to achieve a reduction in fuel costs [20].

Both economic and ecological engine operating indexes depend significantly on the composition of biogas. Due to the fact that biogas can be produced using various technologies, as well as using different substrates, its composition and properties may differ significantly $[2,16]$. Table 2 and 3 show the composition of biogas obtained using its various production technologies and the use of diverse substrates.

Table 2. The composition of biogas depending on the method of its production [2]

\begin{tabular}{|l|c|c|c|}
\hline Komponent & $\begin{array}{c}\text { Agricultural } \\
\text { biogas }\end{array}$ & $\begin{array}{c}\text { Biogas from } \\
\text { energy crops }\end{array}$ & Landfill biogas \\
\hline $\mathrm{CH}_{4}, \%$ & $45-75$ & $57-62$ & $37-67$ \\
\hline $\mathrm{CO}_{2}, \%$ & $25-55$ & $33-38$ & $24-40$ \\
\hline $\mathrm{O}_{2}, \%$ & $0.01-2.1$ & $0-0.5$ & $1-5$ \\
\hline $\mathrm{N}_{2}, \%$ & $0.01-5.0$ & $3.4-8.1$ & $20-25$ \\
\hline $\mathrm{H}_{2} \mathrm{~S}, \mathrm{ppm}$ & $10-30000$ & $24-8000$ & $15-400$ \\
\hline
\end{tabular}

Table 3. Substrates for the production of agricultural biogas and their composition [16]

\begin{tabular}{|l|c|c|c|c|}
\hline Substrat & $\mathrm{N}_{2}, \%$ & $\mathrm{NH}_{4}, \%$ & $\mathrm{P}, \%$ & $\mathrm{CH}_{4}, \%$ \\
\hline Maize silage & $1.1-2$ & $0.15-0.3$ & $0.2-0.3$ & $50-55$ \\
\hline Grass silage & $3.5-6.9$ & $6.9-19.8$ & $0.4-0.8$ & $54-55$ \\
\hline Rye silage & 4.0 & 0.57 & 0.71 & ca. 55 \\
\hline Pig slurry & $6-18$ & $3-17$ & $0.2-1.0$ & $60-70$ \\
\hline Cattle slury & $2.6-6.7$ & $1-4$ & $0.5-3.3$ & 60 \\
\hline
\end{tabular}

One of the most important issues is the percentage share of $\mathrm{CH}_{4}$ in the volume of biogas, which directly translates into such properties as the fuel calorific value. A change in the calorific value results in a change of the engine opera- tion indicators, such as its power and torque. Due to the percentage volume of methane, the calorific value of biogas can vary within very wide limits of $15-27 \mathrm{MJ} \cdot \mathrm{Nm}^{-3}$ [22]. Not without significance is the participation of other substances, including $\mathrm{NH}_{4}$, which may have a negative effect on the engine components causing corrosion.

Research and analysis carried out by many researchers prove the desirability of further work related to the search for solutions that enable the use of energy contained in biogas during combustion in an internal combustion engine [10-12, 17]. Some researchers are focusing on dual-fuel solutions that do not require modifications to the $\mathrm{CI}$ engine design (including reduction of compression ratio, adding of the ignition system) $[9,17,21,23,24]$. As the results of the tests show, the method of controlling the dual fuel engine power is very important, taking into account the engine's operating status. The conducted research also shows the influence of, among other things, the degree of compression on the overall efficiency of the engine and its ecological properties [18].

Some research shows that the dual fuel supply system causes a decrease in the overall engine efficiency. Compared to the supply of only diesel fuel it decreases on average by approximately $17 \%$ (at full load as drop from $29 \%$ to $24 \%$ ). At medium engine loads, the efficiency of the biogas supplied engine is approx. $20 \%$ in the case of unchanged compression ratio compared to the diesel supply. The higher compression ratio has a very favorable effect on emissions, resulting in a decrease of $\mathrm{CO}$ concentration by approx. $30 \%$, HC by approx. $60 \%$, but at the same time an increase in $\mathrm{NO}_{\mathrm{x}}$ emissions by approx. 20\% [18]. Also tests carried out for biogas supply show maximum values of the overall efficiency of the engine of $23.3 \%$ for a load of approx. $54 \%$. This efficiency is slightly higher than with CNG $22,3 \%$. In turn, with supply methane enriched biogas raises the maximum efficiency value to $26.2 \%$ [3]. Similar maximum values of overall engine efficiency were obtained in [15], slightly exceeding $22 \%$.

Due to the required regulations regarding the use of renewable fuels, including Directive 2001/77/EC of the European Parliament and of the Council of Europe on "supporting the production of electricity from renewable sources on the internal market", they increase the share of energy from these sources. An additional decrease in the popularity of first generation bio-fuels (including agricultural crops) for the pressure to increase the second generation of renewable fuels (ie fuels created from products that cannot be used for human or animal food, i.e. most often different types of waste) shows that biogas can be seen as the fuel of the future.

As it results from official statistics presented by government institutions, the share of renewable energy sources in its overall production is still too small, and in particular it concerns the use of biogas in this agricultural biogas [25].

\section{Research methodology}

\subsection{Test bench}

In order to estimate the obtained ecological and economic indicators of the biogas-fueled research engine, a cycle of stationary tests was carried out on a test stand. 
That consisting of an internal combustion engine prepared for operation in a cogeneration system that drives a threephase low power electric machine connected to a 380/400 V network (Fig. 2). In this research program the possibility of heat recovery in the cogeneration system was not taken into account, but only the generation of electricity.

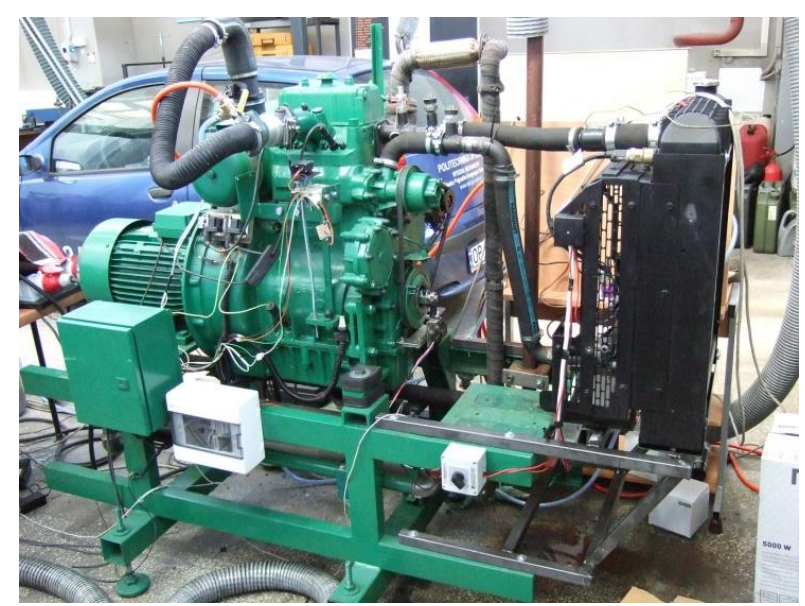

Fig. 2. Test bench

The test engine was modified (Table 4). It was equipped with an ignition system with the possibility of adjusting the ignition advance angle and an electronic control throttle mounted in the intake system and additionally with a high resolution speed sensor.

Table 4. Basic construction parameters of the engine

\begin{tabular}{|l|c|c|}
\hline Parameter & Value & Unit \\
\hline Mark & $\mathrm{S}-312 \mathrm{~B}$ & - \\
\hline Displacement & 1.960 & $\mathrm{dm}^{3}$ \\
\hline Maximum power (Diesel) & 20.6 & $\mathrm{~kW}$ \\
\hline Engine speed for maximum power & 2200 & $\mathrm{rpm}$ \\
\hline Maximum torque (Diesel) & 100 & $\mathrm{Nm}$ \\
\hline Engine speed for maximum torque & $1600-1800$ & $\mathrm{rpm}$ \\
\hline Diameter/ stroke of the piston & $102 / 120$ & $\mathrm{~mm}$ \\
\hline Compression ratio (original) & 17.0 & - \\
\hline Compression ratio after modifications & 15.0 & - \\
\hline
\end{tabular}

Table 5. Basic construction parameters of the electric machine.

\begin{tabular}{|l|c|c|}
\hline Parameter & Value & Unit \\
\hline Mark & Indukta 2SIEL160M4 & - \\
\hline Power supply voltage & 400 & $\mathrm{~V}$ \\
\hline Rated power & 11 & $\mathrm{~kW}$ \\
\hline Rotational speed & 1520 & $\mathrm{rpm}$ \\
\hline Current for rated power & 21 & $\mathrm{~A}$ \\
\hline Maximum torque & 71.95 & $\mathrm{Nm}$ \\
\hline Efficiency with a load $2 / 4$ & 88.2 & $\%$ \\
\hline Efficiency with a load 3/4 & 89.3 & $\%$ \\
\hline Efficiency with a load 4/4 & 89 & $\%$ \\
\hline Number of poles & 4 & - \\
\hline Mass & 105 & $\mathrm{~kg}$ \\
\hline Inertia & 0.061 & $\mathrm{~kg} \cdot \mathrm{m}^{2}$ \\
\hline
\end{tabular}

One of the important goals of modification was to obtain a lower compression ratio compared to the factory configuration of the S-312B engine, for which the compres- sion ratio is $\varepsilon_{\mathrm{f}}=17.0$. As a result of increasing of the combustion chamber volume (realized by reducing the piston height), the compression ratio was reduced to $\varepsilon=15.0$.

A Indukta electric machine with the designation 2SIEL160M4 was connected to the crankshaft of the modified engine. Its basic technical parameters are shown in Table 5 .

\subsection{Fuel supply system}

Due to the biogas composition variability occurring under real conditions, the cogeneration system engine was supplied by a system of gas fuel preparation with variable chemical composition. The biogas power supply system was collecting gases from $\mathrm{CH}_{4}$ methane tanks (Linde Methane 2.5 with a purity of more than $99.5 \%$ ) and carbon dioxide $\mathrm{CO}_{2}$ tanks connected by reducers $\mathrm{R} 1, \mathrm{R} 2$ and gas flow regulators $\mathrm{M}_{\mathrm{CH} 4}, \mathrm{M}_{\mathrm{CO} 2}$. Subsequently, the component streams of individual gases were directed to a tee located near the inlet connector of the mixer mounted in the engine inlet manifold (Fig. 3).

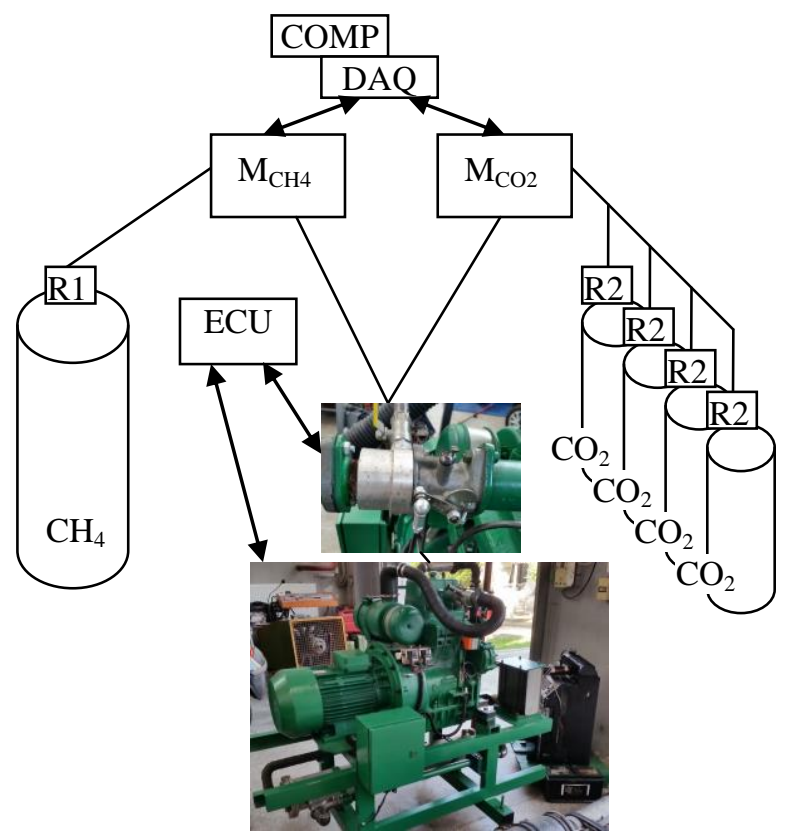

Fig. 3. Diagram of the engine's fuel supply system

The actual flow of the gas components supplied to the test engine was monitored by flow meters mounted on the supply lines of the relevant gas components. As the $\mathrm{CH}_{4}$ methane flow regulator and flow meter, Mass-Stream mass flow regulator D-4371-DR was used to enable gas flow in the range of $0-130 \mathrm{dm}^{3} / \mathrm{min}$. Regulation and measurement of carbon dioxide $\mathrm{CO}_{2}$ flow was achieved thanks to the Bronks mass regulator enabling gas flow in the range of 0 $75 \mathrm{dm}^{3} / \mathrm{min}$.

\subsection{Testing equipment}

The research stand was also equipped with the Motorscan Leader 8000 flue gas analyzer in order to continuously record the gas concentration in the exhaust gases such as $\mathrm{CO}_{2}, \mathrm{CO}, \mathrm{O}_{2}, \mathrm{HC}$ and $\mathrm{NO}_{\mathrm{x}}$.

The parameters of the current flowing between the electric machine and the network were monitored thanks to the 
use of LEM type circuits. In turn, the amount of electricity produced is added up using the Orno OR-WE-505 meter with pulse output. In order to measure the current generated by the generator and the voltage in individual circuits of the 3-phase system, the HASS 50-S current transducer is included in the measuring path (Fig. 4).

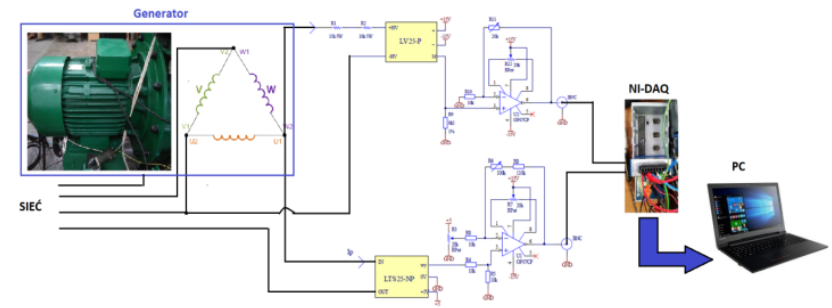

Fig. 4. Connection of the HASS 50-S current transducer with a test bench

The registration of all cogeneration system operation parameters (engine and electric machine) was possible thanks to the measurement system consisting of the National Instruments Compact DAQ module and the NI 9201 measuring card based on measurement system created in the LabView environment.

\section{Results}

The aim of the conducted research was to determine the impact of the throttle opening regulation and the composition of the gas mixture feeding the tested engine on system operation indicators such as electricity production and emission of harmful substances. The tests were carried out for different proportions of the $\mathrm{CH}_{4}-\mathrm{CO}_{2}$ gas mixture. Four types of gas mixture with the following $\mathrm{CH}_{4}$ content were determined (in relation to the total flow thru the inlet of the mixer: $100 \%, 75 \%, 60 \%, 50 \%$. So at example the mixture with volumetric participation of $75 \%$ of $\mathrm{CH}_{4}$ and $25 \%$ of $\mathrm{CO}_{2}$ will be further called $75 / 25$. Simultaneously a gradual change of the throttle in the range of $10-100 \%$ was made (Fig. 5).

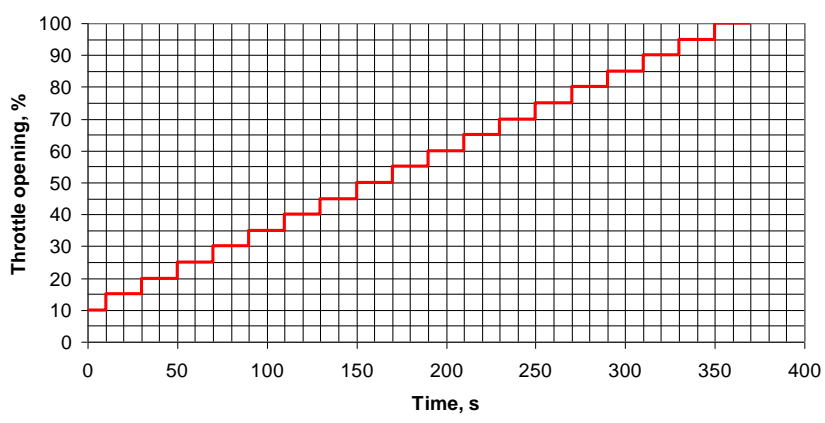

Fig. 5. The method of gradual throttle opening during the test

The results of tests and their analysis for fuelling the engine with gas mixtures with different $\mathrm{CH}_{4}$ volume contents are presented below, however for a given $\mathrm{CH}_{4}$ constant flow rate of $60 \mathrm{dm}^{3} \cdot \mathrm{min}^{-1}$.

\subsection{Mechanical and electrical operation indicators}

One of the important factors to assess the operation of a system consisting of an internal combustion engine and an electric machine is the generated electricity power and also the rotational speed. The diagrams show the course components of electric power as the active, relative and apparent power. However, the most important is the comparison of active power values. Analyzing the time courses it can be stated that the value of active electric power in the initial phase increases rapidly together with the increase of throttle opening value. Exceeding, however, a certain value causes a sudden drop in electric power. To power the engine with a 100/0 gas mixture (pure methane), the highest values of active power $(7.5 \mathrm{~kW})$ occurring at the throttle opening of approx. 30-35\% were obtained.

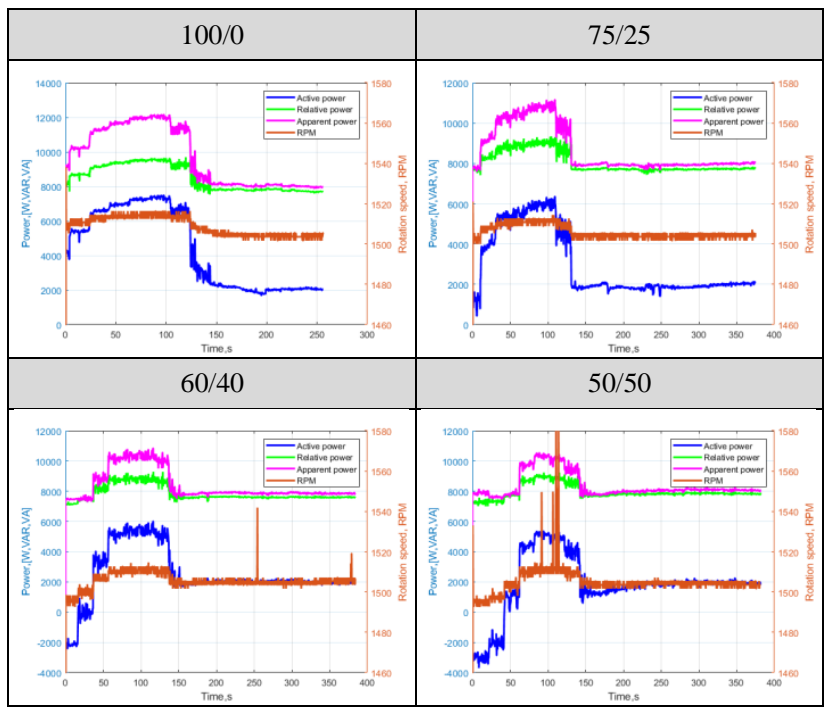

Fig. 6. Course of electrical powers and engine rotational speed at supply of different gas mixture

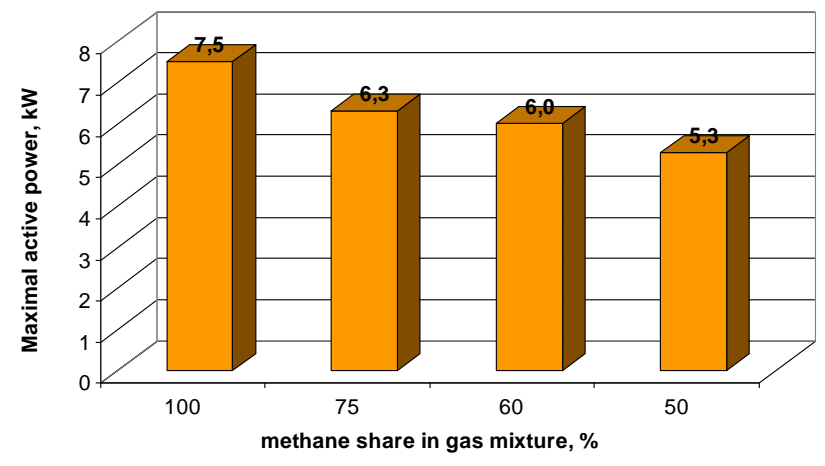

Fig. 7. Maximum value of active electrical power

For mixtures of gases with small share of methane, the maximum power values are respectively: for the $75 / 25$ mixture $6.3 \mathrm{~kW}$, for $60 / 406.0 \mathrm{~kW}$ and for the case of $50 / 50$ fuel at $5.3 \mathrm{~kW}$ (Fig. 6, 7).

\subsection{Ecological operation indicators}

From the point of view of environmental impact, the emission of harmful substances should be monitored. The waveforms show the concentration patterns in the exhaust of individual harmful substances (Figs 8-10).

When analyzing the $\mathrm{HC}$ concentration in flue gas waveforms, it should be noted that the smallest values correspond to the throttle opening with obtaining the highest value of electric power (Fig. 8). However, supplying the 
engine with a poorer methane mixture results in an increase in the HC concentration by several dozen percent (at the point of maximum electrical power of the system). In turn, the concentration of $\mathrm{CO}$ in the flue gas decreases with the increase of the throttle opening. Referring to the engine operation area associated with the maximum electrical power, it can be seen that it is close to the low CO concentration (Fig. 9).

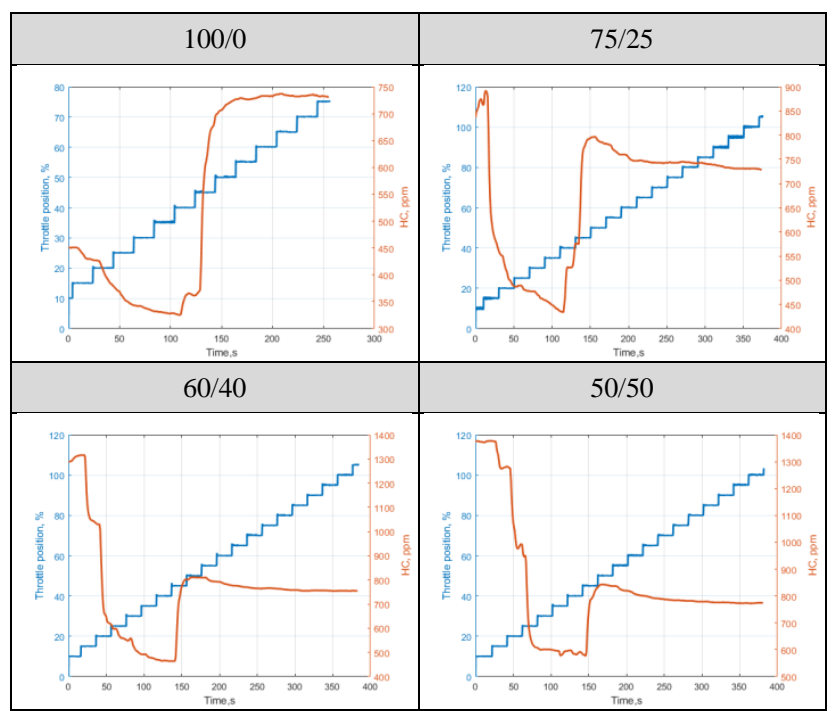

Fig. 8. Concentration of $\mathrm{HC}$ in the exhaust gases at supply of different gas mixture

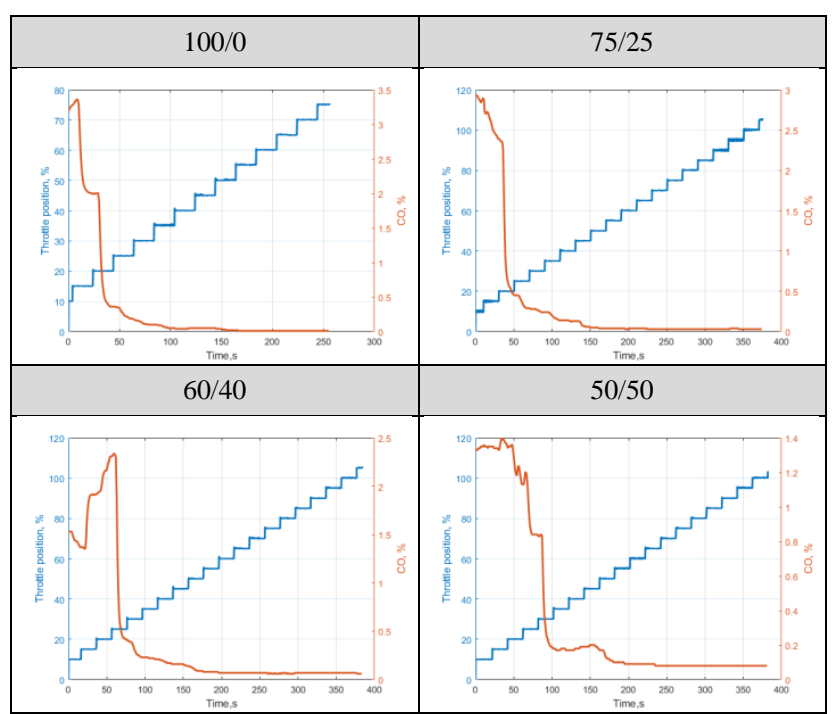

Fig. 9. Concentration of $\mathrm{CO}$ in the exhaust gases at supply of different gas mixture

Also in this case, the supply of a gas mixture with a lower volume fraction of methane may cause an increase in the concentration of $\mathrm{CO}$ in the exhaust. Analyzing the course of $\mathrm{NO}_{\mathrm{x}}$ concentration, it can be seen an its increase in case of the high share of methane at supply mixture gases. In addition, high $\mathrm{NO}_{\mathrm{x}}$ concentration values coincide with the throttle opening responsible for achieving maximum system efficiency (Fig. 10).

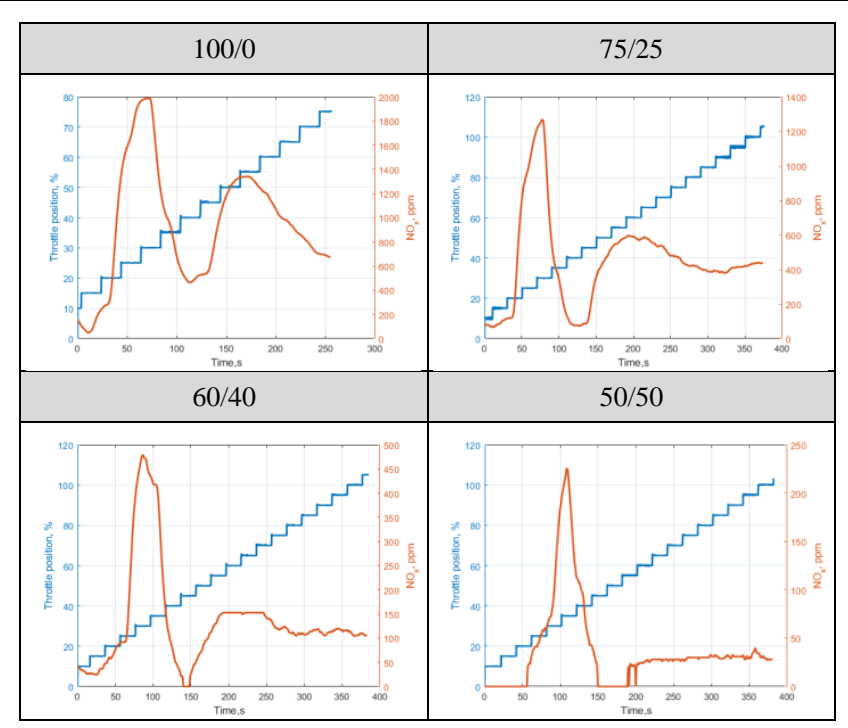

Fig. 10. Concentration of $\mathrm{NO}_{\mathrm{x}}$ in the exhaust gases at supply of different gas mixture

$\mathrm{NO}_{\mathrm{x}}$ concentration in the exhaust gas corresponding to the area of maximum efficiency is for the fuel supply with a high methane content (100/0) many times higher than for the case of its low volume fraction (50/50).

\subsection{Fuel consumptions and overall efficiency}

For many users of electrical energy systems, their economic properties are very important. For this reason, examples of specific fuel consumption courses are presented (Fig. 11).

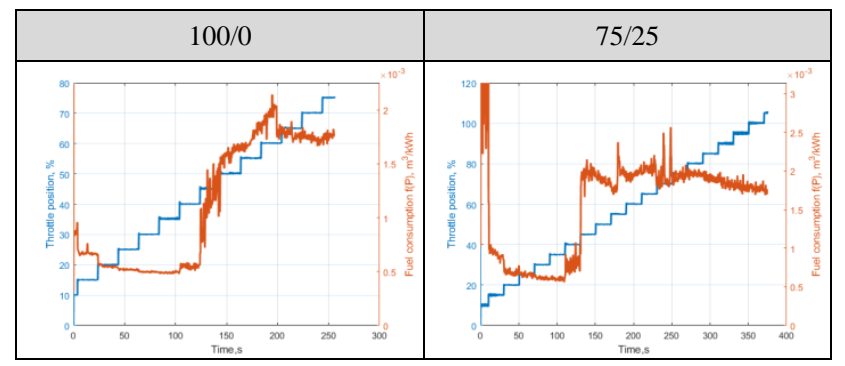

Fig. 11. Course of unit fuel consumptions

Its lowest values were recorded in the area of the highest electric power and they amount to $0.48 \mathrm{~m}^{3} / \mathrm{kWh}$ for 100 $\%$ methane content and exceed $0.6 \mathrm{~m}^{3} / \mathrm{kWh}$ for gas containing less than $60 \%$ methane (Fig. 12).

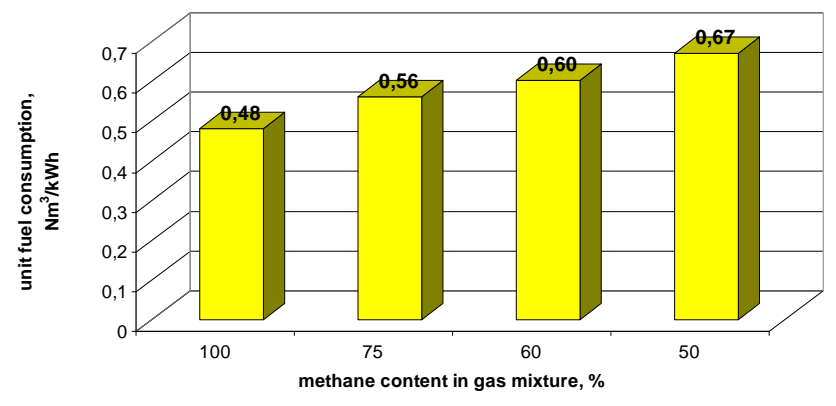

Fig. 12. Minimum unit fuel consumptions 
The overall efficiency of the electricity generating system containing the internal combustion engine and the electric machine is determined as follows:

$$
\eta_{\mathrm{eA}}=\frac{\mathrm{P}_{\mathrm{A}}}{\mathrm{v}_{\mathrm{CH} 4} \mathrm{~W}_{\mathrm{u}}} \cdot 100
$$

when calorific value of methane: $\mathrm{Wu}=35730 \mathrm{~kJ} \cdot \mathrm{Nm}^{-3}$.

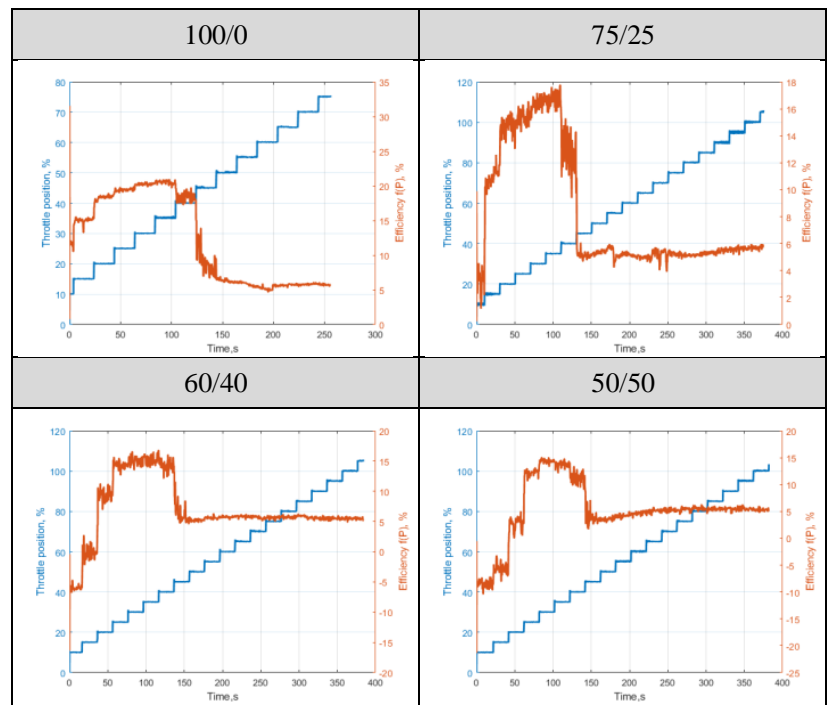

Fig. 13. Electricity generating system efficiency at supply of different gas mixture

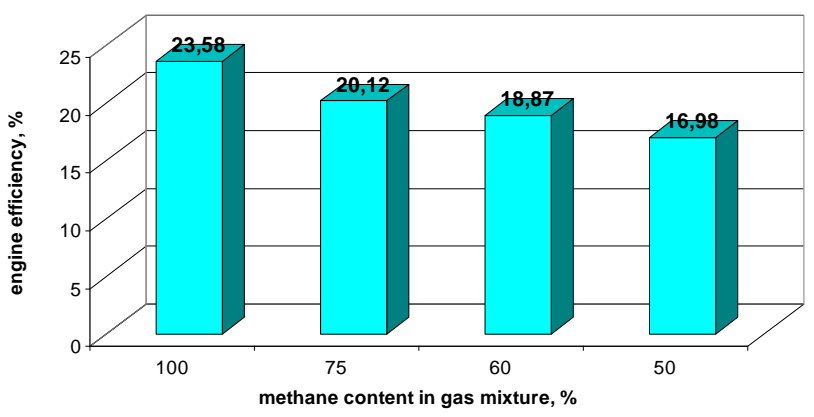

Fig. 14. Impact of throttle position on engine overall efficiency
As shown by the analysis of the overall efficiency of the engine-electric machine (Fig. 13), there is a clear range of throttle opening, where the highest efficiency value is obtained. It occurs for throttle up to 30-35\%. Taking into account the efficiency of the electrical machine (Table 5), it is possible to estimate the overall efficiency of the internal combustion engine (Fig. 14).

Its highest values are obtained for the gas mixture with the highest methane content, amounting to $23.58 \%$.

\section{Conclusions}

Use of biogas to supply a high compression engine can have measurable benefits both ecological and economical engine operating indexes. Obtained high efficiency is associated with the appropriate selection of the drive unit (matching the engine characteristics constant rotational speed of about $1500 \mathrm{rpm}$ ) but also with the appropriate control. As the research shows, in addition to the basic control elements such as the throttle and the regulation of supply gas stream, the obtained results are also significantly affected by the biogas composition. Low methane contents result in a decrease in the overall system efficiency and also in increased emissions of harmful substances. At the same time, the unit fuel consumption increases with respect to the drop of produced electricity. The most advantageous values of unit fuel consumption in the case of engine fuelling with low methane content $(50 \%)$ biogas is $0.67 \mathrm{Nm}^{3} \cdot \mathrm{kWh}^{-1}$, and with high methane content $(100 \%)$ allows to improve it by almost $30 \%\left(0.48 \mathrm{Nm}^{3} \cdot \mathrm{kWh}^{-1}\right)$. For this reason, one should strive to improve the methods allowing to increase the methane content in biogas, eg due to the reduction of the $\mathrm{CO}_{2}$ in biogas volumetric concentration.

\section{Acknowledgements}

This work is co-funded from European Union from the European Regional Development Fund as part of the Regional Operational Program of the Opolskie Voivodeship for 2014-2020 in scope of project: "Undertaking industrial research and development work by Ekoamret Ltd. aimed to introduce on the market innovative micro cogeneration CHP unit based on biogas powered internal combustion engine".

\section{Nomenclature}

CHP combined heat and power

CI compression ignition

COMP computer

DAQ Data Acquisition Station

ECU Electronic Control Unit

$\mathrm{M}_{\mathrm{CH} 4} \quad \mathrm{CH}_{4}$ mass flow regulator

$\mathrm{M}_{\mathrm{CO} 2} \quad \mathrm{CO}_{2}$ mass flow regulator

MON motor octane number $\mathrm{e}_{\mathrm{f}} \quad$ compression ratio of Diesel engine

e compresssion ratio after modifications

$\eta_{\mathrm{eA}} \quad$ overall electricy generating system efficiency, \%

$\mathrm{P}_{\mathrm{A}}$ active power, $\mathrm{kW}$

$\mathrm{R} 1, \mathrm{R} 2$ gas reductor

$\mathrm{V}_{\mathrm{CH} 4}$ methane consumption, $\mathrm{Nm}^{3} \cdot \mathrm{s}^{-1}$

$\mathrm{Wu}$ callorific value of methane, $\mathrm{kJ} \cdot \mathrm{Nm}^{-3}$

\section{Bibliography}

[1] BIENIEK, A., MAMALA, J., GRABA, M., PRAŻNOWSKI, K. Possibilities to improve emission property of compression ignitron engine by applying of catalytic fuel additives. Combustion Engines. 2015, 162(3), 968-977.

[2] CEBULA, J. Biogas puryfication by sorption techniques. ACEE Journal. 2009, 2, 95-103.
[3] CHANDRA, R., VIJAY, V.K., SUBBARAO, P.M.V., KHURA, T.K. Performance evaluation of a constant Speer IC engine on CNG, methane enriched biogas and biogas. Applied Energy. 2011, 88, 3969-3977.

[4] CIEŚLIKOWSKI, B., KNAPIK, P. Adaptacja konstrukcji ciągnika rolniczego C-385 do zasilania CNG. Inżynieria rolnicza. 2007, 9(97), 35-40. 
[5] HEPNER, W., HETMAŃCZYK, I., BIENIEK, A. Gaz generatorowy - kryzysowe paliwo silnikowe. Siniki Gazowe. 2010, 269-279.

[6] HETMAŃCZYK, I., HEPNER, W., BORECKI, D., BIENIEK, A. Zagadnienia regulacji i sterowania silnikiem spalinowym zasilanym wodorem. Silniki Gazowe. 2010, 280289.

[7] LEJDA, K., JAWORSKI, A. Zasilania gazowe silników rolniczych. Motorol. 2006, 131-138.

[8] MERKISZ, J., PIELECHA, I. Alternatywne paliwa i układy napędowe. Wydawnictwo Politechniki Poznańskiej. Poznań 2006.

[9] MIKULSKI, M., WIERZBICKI, S., ŚMIEJA, M., MATIJOŠIUS, J. Effect of CNG in a fuel dose on the combustion process of a compression-ignition engine. Transport. 2015, 30(2), 162-171. DOI: 10.3846/16484142.2015.1045938

[10] von MITZLAFF, K. Engines for biogas. Deutsches Zentrum fur Entwicklungstechnologien GATE. 1988.

[11] PIĘTAK, A., RADKOWSKI, S., Methane - a fuel for agriculture. Journal of KONES. 2011, 18(4), 357-358

[12] PODESZWA, E., BIERNAT, K. Biogaz jako alternatywny nośnik energii. Studia Ecologiae et Bioethicae UKSW. 2014, 12(2), 131-138.

[13] PRZYBYŁA, G. Wpływ paliw gazowych na parametry pracy tłokowego silnika spalinowego pracującego w układzie CHP. ISING Artykuty referencyjne Biblioteki Źródtowej Energetyki Prosumenckiej. www klaster3x30.pl, 2014, 1-13.

[14] SIRIPORNAKARACHAI, S., SUCHARITAKUL, T. Modification and tuning of multi-valve diesel bus engine to run on biogas for electricity production. International Journal of Renewable Energy. 2018, 3(2), 1-13.

[15] SWAMI NATHAN, S., MALLIKARJUNA, J.M., RAMESH, A. An experimental study of the biogas-diesel HCCI mode of engine operations. Energy Conversion and Management. 2010, 51, 1347-1353.
Andrzej Bieniek, DEng. - Faculty of Mechanical Engineering, Opole University of Technology.

e-mail:a.bieniek@po.opole.pl



Jarosław Mamala, DSc., DEng. - Faculty of Mechanical Engineering, Opole University of Techno$\log$.

e-mail:j.mamala@po.opole.pl



Mariusz Graba, DEng. - Faculty of Mechanical Engineering, Opole University of Technology. e-mail:m.graba@po.opole.pl
[16] SZLACHTA, J., FUGOL, M. Analiza możliwości produkcji biogazu na bazie gnojownicy oraz kiszonki z kukurydzy. Inżynieria Rolnicza. 2009, 5(114), 275-280.

[17] ŚMIEJA, M., WIERZBICKI, S. Analysis of potential application of biogas fuel in modern compression-ignition engines. Environmental Engineering - 10th International Conference Vilnus Gediminas Technical University. 2017, 1-7. DOI: 10.3846/enviro.2017.035

[18] TAREMWA, A., KIPLIMO, R., WANJII, S. Effect of compression ratio on the performance and emission of diesel dual fuel engine using biogas. IOSR Journal of Mechanical and Civil Engineering (IOSR-JMCE). 2016, 13(3), 67-74.

[19] TUROWSKI, S., NOWOWIEJSKI, R. Analiza układu kogeneracyjnego jako źródła ciepła i energii elektrycznej w modelowym gospodarstwie rolnym. Inżynieria Rolnicza. 2009, 1(110), 331-338.

[20] WEYMANN, S. Zasilanie gazowe silników ciągników rolniczych. Technika rolnicza ogrodnicza leśna. 2016, 1, 20-22.

[21] WIERZBICKI, S. Studium wykorzystania biogazu do zasilania silników o zapłonie samoczynnym. Wydawnictwo UWM. Olsztyn 2016.

[22] WIERZBICKI, S., MIKULSKI, M. Wykorzystanie biogazu do zasilania silników o zapłonie samoczynnym pracujących w układach kogeneracyjnych. Studies \& Proceedings of Polish Association for Knowledge Management. 2014, 70, 138-150.

[23] WIERZBICKI, S., ŚMIEJA, M. Use of biogas to power diesel engines with common rail fuel systems. MATEC Web of Conferences. 2018, 182, 01018, 1-8. DOI: 10.1051/ matecconf/201818201018.

[24] WIERZBICKI, S. Biogas as a fuel for diesel engines. Journal of KONES Powertrain and Transport. 2012, 19(3), 477482 .

[25] ZIÓŁKOWSKI, M., BALCERSKI, A. Silniki spalinowe zasilane biogazem jako perspektywa polskiej energetyki rozproszonej. Scientific Journals Maritime University of Szczecin. 2009, 17(89), 92-97.

Krzysztof Prażnowski, DEng. - Faculty of Mechanical Engineering, Opole University of Technology.

e-mail: k.praznowski@po.opole.pl

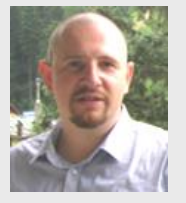

Michał Śmieja, DEng. - Faculty of Technical Science, University of Warmia and Mazury. e-mail: smieja@uwm.edu.pl

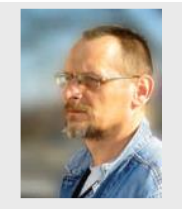

Dariusz Wereszczyński, MSc. - EKOAMRET Sp z o.o., Opole.

e-mail: dw@ekoamret.pl 